\title{
PERSONAL REFLECTIONS
}

\section{Organisation For The Relief Of Concentration Camps}

\author{
HO Engel
}

\section{ABSTRACT}

Objective- To review the essential principles involved in rescue missions for natural and man-made disasters.

Method- A description of the relief of a concentration camp in 1945 as an example of the logistics required in any major disaster or rescue.

Results- The arrival of trained Army rescue teams on the first day and dealing systematically with priorities in salvage, treatment and nursing saved many lives, even of desperately ill patients.

Conclusions- A centralised administration and organisation of supplies is the first priority. Suitable intravenous and very light nutrients, and the prevention and combating of infections are more urgent than the provision of shelter and clothing.

\section{Introduction}

Not a month goes by without emergencies occurring somewhere, arising from the environment (volcanoes in Congo, floods in Mozambique or Bangladesh, drought in Ethiopia, earthquake in Gujarat), or manmade, international or civil war, (as in Yugoslavia or Congo) or "ethnic cleansing" as in Nazi Germany or Kosovo.

Urgent rescue and relief follows a fairly standard pattern $(1,2)$, wherever the catastrophe occurs, but the principles we learnt during the liberation of concentration camps at the end of World War II may be applicable 58 years later, and bear repeating, because they often have to be relearnt as new emergencies occur.

Relief agencies like "Médecins sans Frontières" and Oxfam often arrive within days, provided access is possible, but supplies always take time to arrive and tend to peter out after the media have lost interest. The first supplies to be collected and distributed are generally tents and clothing, but these are not as urgent as clean water and suitable nutrition and the control of infectious disease.

The author was able to compare the horror camps run by the SS with those he experienced personally 5 years previously as a "friendly alien", following the panic created

HO Engel

Dr HO Engel FFOM 58 Whitehouse Way, London, N14 7LT by the evacuation of Dunkerk in May 1940. That emergency consisted of a complete unpreparedness of the Army to provide and run internment camps.

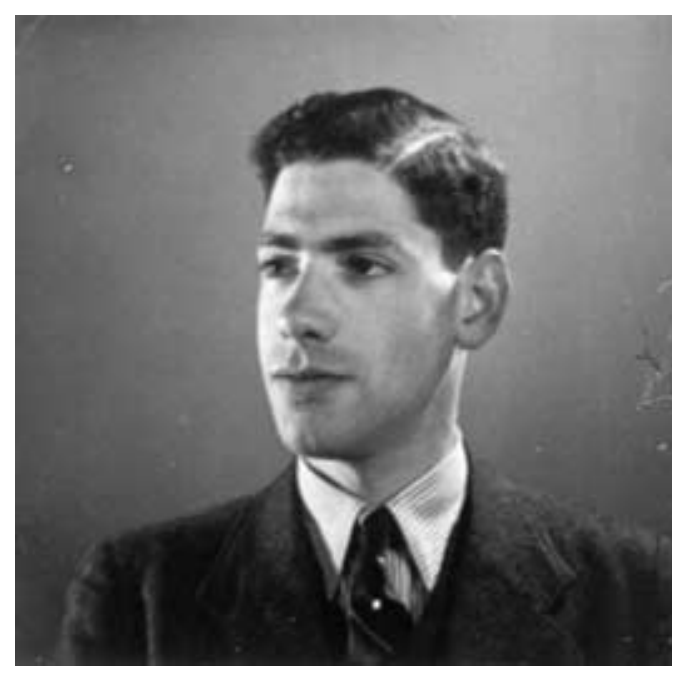

Fig 1. The Author 1943

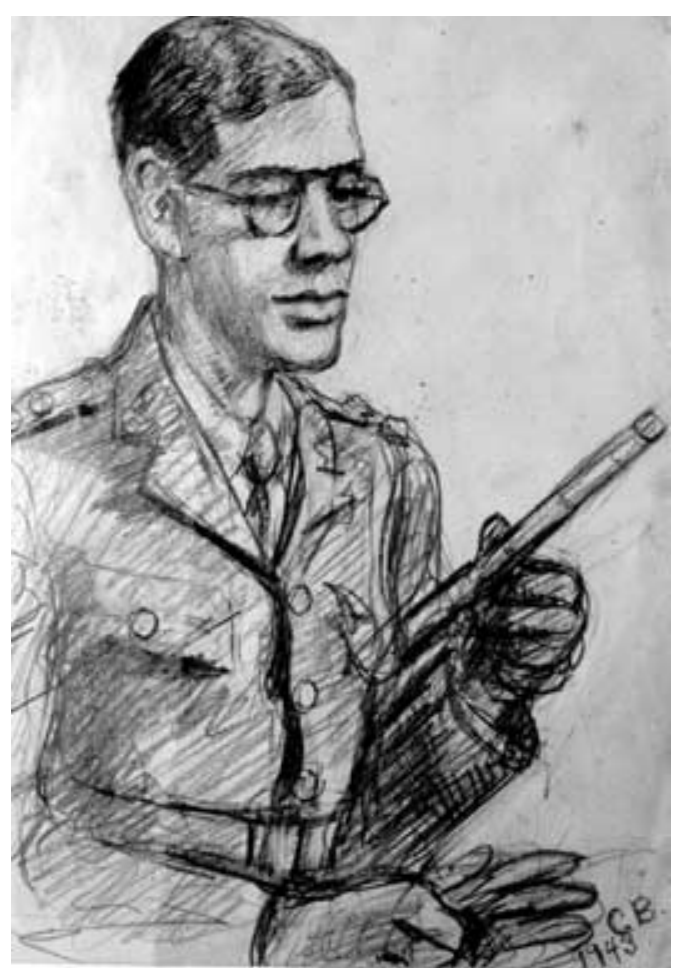

Fig 2. The Author 1945.

The nightmare started with a policeman calling at my hospital in Edinburgh to take me to Donaldson's 'Hospital' school, taking only 'pyjamas and a toothbrush'. After sleeping there on the concrete floor for a few days, we were transferred to a tented camp in Huyton and fairly comfortable boarding houses on the Isle of Man, but still without letters, parcels in or out, newspapers or radio. Next a nightmare crossing in the ship 
"Ettrick" to Canada, spending 22 hours a day in the hold, with 2,600 German POWs, seamen, refugees and Jews, in hammocks practically touching each other. Everybody had diarrhoea from food poisoning, and queued day and night for 4 large pails in lieu of toilets. The behaviour of the Major in charge of that transport I believe earned him a well deserved court martial after the War.

In the nine months detained in the Canadian camps the main hardship, apart from the lack of bedding, was a completely pointless daily roll call, when all internees had to stand in severe winter weather for over an hour while a young Lieutenant called everyone's names. However, in these conditions the lack of organisation by the Army never caused an emergency in the least comparable to those in Germany, deliberately engineered by the SS extermination camps.

\section{Methods}

Only weeks before the end of the war in Europe the Nazi SS were determined to eliminate thousands of slave labourers held in camps in Germany and Eastern countries, and in forced hunger marches they were moved ever farther North in face of the advancing British and Canadian armies. Those who survived these hunger marches ended up in large camps like Belsen and Sandbostel on the Lüneburg Heath, when the SS could no longer hide or quietly 'exterminate' them. In April 1945, just before the surrender, these 'political' prisoners were left to starve. The male prisoners originated from 15 occupied countries including Russia, Ukraine, France, Belgium and Italy. Starvation and infectious diseases, typhus, typhoid and dysentery were prevalent. Thousands died before relief could be brought.

Rescue teams from the British Royal Army Medical Corps had the great advantage of being on the spot from the first day of liberation, and having been trained and equipped for treating casualties. The first large camp in Belsen held 55,000 slave labourers in varying degrees of starvation and illness. Belsen was liberated on 15 th April 1945, and the conditions and the efforts of Army, Red Cross and doctors and students from England have been widely reported. In fact numerous articles have been published, well summed up in this Journal (3), and the latest quotes 71 references (4). That the Army medical services were unprepared for the number of prisoners and their desperate state is clear when one reads that the camp medical commander, Lt Col JAD Johnston, entered the camp on the 17 th, and made his report quickly, asking for urgent supplies the next day. Expert help from England, however, did not arrive till the 1 st May, 15 days later.

A smaller concentration camp in
Sandbostel was not liberated till 29th April and no comparable articles have been published about it.

On the 27th April the DDMS 2nd Army, Brig Glyn Hughes had driven me all over Lüneburg Heath, expecting the camp to be freed immediately. But the German Army tenaciously defended the crossing of the Oste river and the Grenadier Guards Armoured Division could not liberate the camp till the 29th. Capt R Barer of the 94 Light AA Regt RA, who was seconded to them, has written a graphic account of the horror he found there (5) and wrote a report with a list of urgent supplies the same day, that formed the basis of our relief operations

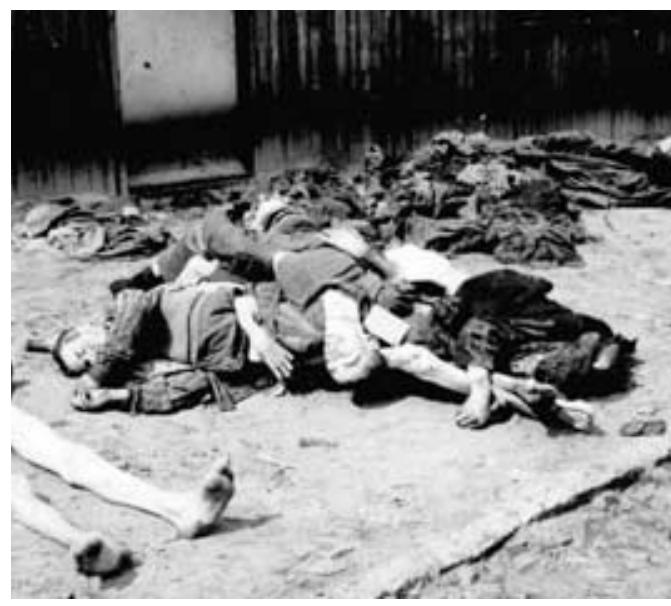

Fig 3. The camp two days after liberation.

Sandbostel concentration camp held about 10,000 inmates. Its prisoners had been without food or water for over a week; many had severe infections. I arrived on the day of liberation with 3 RAMC Medical officers and 100 other ranks. 3000 unidentified dead bodies were lying unburied in the open (6). 7000 survivors were crammed into huts, lying in their excrement on wooden bunks or on the filthy floor, some too weak to push a dead comrade off the litter. The stench and dirt were indescribable. But our rescue work was much better organised than that in Belsen, because the DDMS had had two weeks' experience in the relief of that camp, and the liberation of British prisoners of war freed medical personnel and Red Cross supplies, which were rapidly diverted to relief of concentration camps. We also had help from French doctors from the adjoining POW camp, which was being run more or less according the Geneva convention

\section{Infection control}

First the Field Hygiene Sections doused everybody with DDT from head to foot, to kill typhus lice. All armed forces personnel had been vaccinated annually for typhus and typhoid, but this was thought to be only $60 \%$ effective. Due to this disinfestation no Army personnel developed typhus, although in Belsen some cases occurred, and also in some of the German civilians whom we 
conscripted to help in cleaning these Augean stables. Sulphonamides had recently become available and were ordered by Capt Barer to treat dysentery and other infections.

\section{Water}

Next we brought in clean water by a convoy of tanker trucks, until the water supply was restored.

\section{Infusions}

We were fortunate that anaesthetic teams became available early on, as fighting had practically ceased. They could intubate collapsed veins of the emaciated patients, where ordinary medical officers failed. We administered glucose-saline and plasma until vomiting and diarrhoea stopped. Many patients in extremis were saved by these intravenous infusions.

\section{Milk drinks}

Fortunately Red Cross food parcels were no longer required for POWs, who were being rapidly repatriated, and could be diverted at once to the camps.

I appointed two orderlies to brew up warm sweet milk drinks from the milk powder, Horlicks, Ovaltine and chocolate in a large cauldron all day: for the first days this was the only nutrition we allowed the inmates.

Soon afterwards we obtained field kitchens, enabling us to provide suitable light diets. Two weeks earlier some prisoners had stormed the German food stores, but many of those who were not shot (300 men), died from unsuitable food they had bolted down in desperation. The French POWs in the adjoining camp used to throw solid food over the fence, probably killing quite a few, till their medical officer stopped their well meant lethal gestures.

In Belsen many prisoners were fed through gastric Ryle's tube $(7,8)$. This is a treatment we would never have contemplated, because confused victims would have thought it another Nazi torture.

\section{Nursing}

Prisoners who could be moved were taken to a cleansing hut, where they were washed thoroughly and shaved all over, before being transferred to clean stretchers and huts. We were permanently short of helpers and had to conscript large numbers of nurses from the big hospitals in Hamburg and Bremen and many civilians from nearby towns and villages. At first their matron stated that they refused to risk their health for such "subhumans". But after a furious lecture given to them in German by me and the example of the RAMC personnel, who worked day and night to save lives, they soon knuckled under and did most of the cleaning and nursing. Three weeks later this matron told me that she had never been so ashamed of being a German as the day I gave them my lecture.

Next we built adequate latrines with hand washing facilities.

A field laundry and mountains of blankets were imported by Ordinance; the blankets had to serve as temporary clothing after all the remaining prison garb had been burned. Boots, socks and clothes followed soon after. A Field Dressing Station (3 Medical Officers and 100 medical orderlies) was brought in on 2nd May and a 600-bed CCS-hospital on 6th May, which was immediately overfilled. In fact, despite the best organisation by the RAMC directorate, there were never enough beds, nurses and helpers until three weeks after liberation.

\section{Results}

However, a month after the rescue only a small number of the survivors remained desperately ill, mostly with tuberculosis. When the camp was liberated some 3000 prisoners were already dead. We will never know how many of the 7000 inmates, near death on our arrival, survived in this camp due to our efforts. But we know that thousands had succumbed on the death marches and in extermination camps, before the Allied Armies could stop the murders by the SS (SchutzstaffelTotenkopf-verbaendre), the SS branch specially charged to deal with "political" prisoners, and aptly called 'death-head' units.

\section{Discussion}

The main lessons we learnt from this emergency rescue were:

All rescue and resuscitation must be coordinated by a single director (in this case the Deputy Director of Medical Services), who decides on priorities of supplies. This usually means water, food, infusions and prevention of infection, before shelter and clothing, which are less urgent in lifesaving.

Nutrition is the most urgent task: provision of ample intravenous fluids and trained phlebotomists (doctors or paramedics), with glucose-saline and plasma (then immediately availablenowadays hetastarch solutions and protein hydrolysate).

Clean drinking water, in this camp inmates were drinking filthy water from puddles in the grounds

Warm sweet milk drinks, as this is often the only food that can be retained after vomiting and diarrhoea have stopped.

Speed is of the essence, because those with few reserves may die daily in large numbers. Some died suddenly, seemingly well on the road to recovery, a setback also observed in other camps and so far unexplained. We know that many hundreds had died every day in this camp alone, and 
it remains a puzzle that German soldiers contested the river Oste crossing for days, only a week before the armistice, when the SS camp guards had already long fled the camp.

\section{References}

1. Lumley JSP, Ryan JM, Baxter PJ , Kirby N Handbook of the Medical Care of Catastrophes Rl Soc Med Press 1996.

2. Ryan JM, Mahoney PF, Greaves I, Bowyer G. Conflict and Catastrophe Medicine, a practical guide. London Springer 2002.
3. Collis WRF. Belsen Camp: a preliminary report. Br Med J 1945; 1: 814-816.

4. Trepman E. Rescue of the Remnants: The British Emergency Medical Relief Operation in Belsen Camp 1945.J R Army Med Corps 2001; 147: 281293.

5. Barer R. One Young Man and Total War. Edinburgh, Pentland Press 1998; 276-289.

6. Borgsen W, Volland K. Stalag XB Sandbostel. Bremen, Ed. Temmen 1991

7. Paton A. Mission to Belsen 1945. Br Med J. 1981; 283:1656-1669.

8. Engel H. Mission to Belsen 1945 Br Med J 1982; 284: 269. 